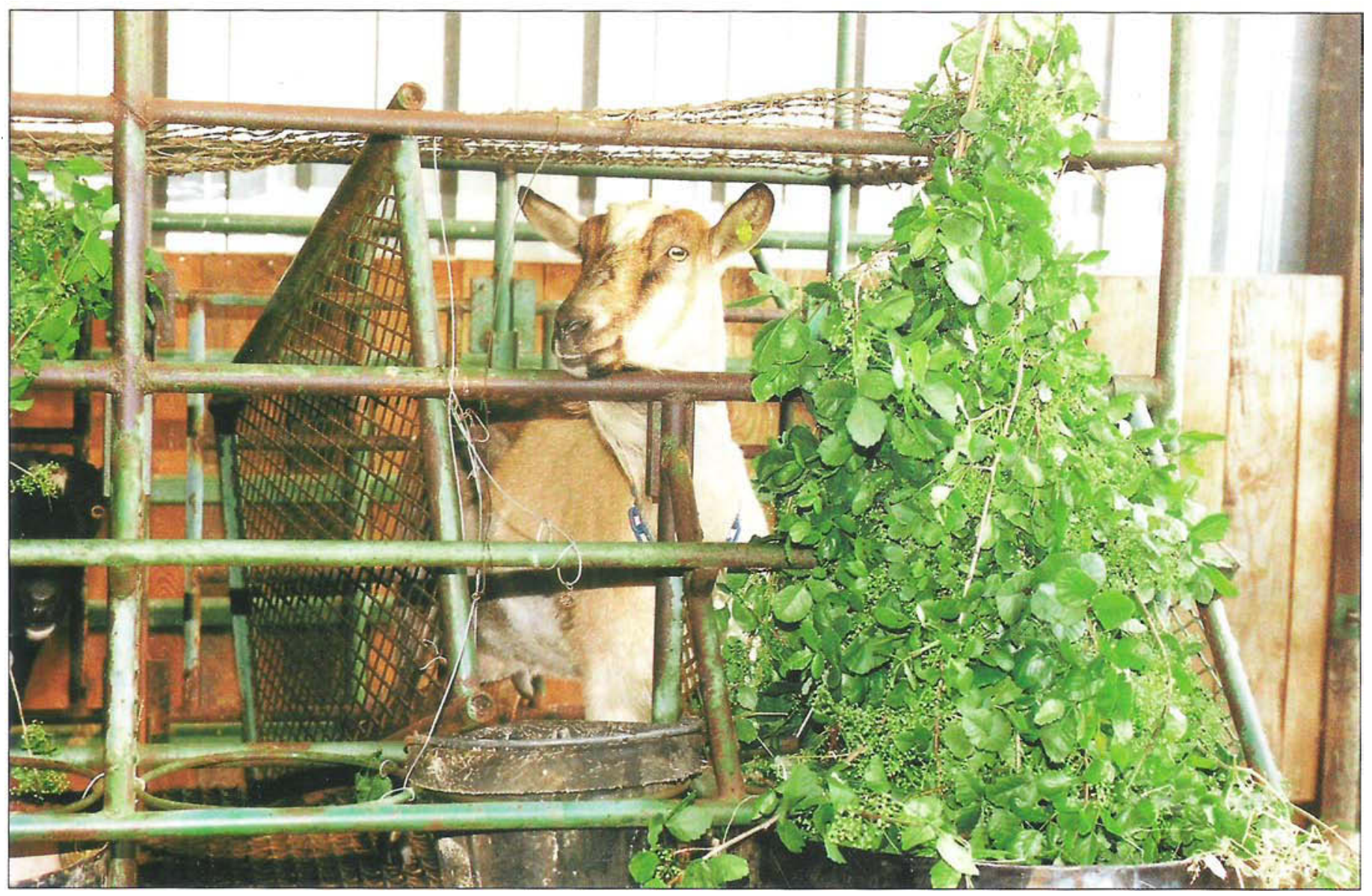

A dairy goat eats poison oak in a feeding station at UC Davis.

Initial research indicates ...

\title{
Dairy goats used to clear poison oak do not transfer toxicant to milk
}

\author{
Brou Kouakou $\square$ David Rampersad $\sqcup$ Eloy Rodriguez $\square$ Dan L. Brown
}

\begin{abstract}
Dairy goats that eat poison oak do not transfer detectible amounts of the toxic principle, urushiol, to the milk or to the urine. Furthermore, this oily, toxic irritant is found in goat manure at less than $9 \%$ of its concentration in poison oak leaves. What does all this portend? That farmers using dairy goats to clear poison oak need not worry about contaminating the goats' milk with urushiol. More studies are underway.

Most Californians are familiar with the painful, often debilitating skin rash (dermatitis) that can result from contact with poison oak. In the United States, three native species of the genus
\end{abstract}

Toxicodendron are often cited for their ability to induce the dermatitis: Pacific poison oak (Toxicodendron diversilobum), mostly found on the Pacific West Coast; poison ivy ( $T$. radicans), found east of the Rocky Mountains; and poison sumac (T. vernix), present in the swamps of the South.

The active principles causing poison oak dermatitis make up a family of oleoresins, referred to collectively as urushiol The dermatitis is the result of an allergic reaction, not to urushiol itself but, rather, to the combination of urushiol and the victims' own skin proteins.

Poison oak urushiols consist of catechol rings with a hydrocarbon side chain at the 3 position. Most poison oak urushiols (98\%) have side chains 17 carbons long with one, two or three double bonds (see fig. 1). An oxidized form of the catechol ring does the binding, while the long side arm helps the skin absorb this toxicant. Polyunsaturated side arms are thought to cause a more serious reaction than saturated ones.

\section{Control of poison oak}

Eradication of poison oak is the only completely effective method for preventing occupational exposure. Theoretically, digging up the entire plant and burning it is the best method of eradication, but it is prohibitively expensive and exposes workers to extremely hazardous smokeborne urushiol. Biological control appears to be the best way to reduce these poisonous plants, in view of the many barriers to other ways: legal restrictions, environmental hazards, health concerns and/ or the expense of using herbicides, such as glyphosate (Roundup) or triclopyr (Garlon). By itself, 2,4-D does not work 
very well on poison oak, and 2,4,5-T is no longer legal for this application.

Goats have been used to open up grazing lands for other livestock and also for brush control. Browsing and resulting defoliation of brush by goats lead to subsequent reduction of plant carbohydrate reserves, thereby eventually killing the plants. Goats could be used to inexpensively control poison oak in pasture land and recreation areas. With proper management this can be accomplished with relatively little damage to nontarget plant species and to the environment.

Because the fate of urushiol ingested by goats is unknown, a concern exists for the safety of people using goat dairy products from poison oak-fed goats. This concern, in addition to American folklore crediting milk from poison oak-fed goats with inducing tolerance, led to testing the following hypotheses:

(1) Urushiol and/or its metabolites will be found in the milk, urine and feces of goats consuming poison oak.

(2) Dairy goats fed poison oak will convert unsaturated urushiol to saturated metabolites.

\section{Trial I: poison oak as supplement}

Six lactating goats at the UC Davis (UCD) Dairy Goat Facility were fed mature poison oak free choice for 3 days, in addition to their daily feed allotment of 2 $\mathrm{kg}$ of corn-alfalfa pellets. The plant material for this trial was collected from the Oak Regeneration Research Plot at the Sierra Foothill Range Field Station, transported to the dairy goat facility and stored under cover until fed to goats. The foliage was weighed, offered as leaves and stems, and the refused feed (predominately stem) weighed the following morning. Total intake was $840 \mathrm{~g} / \mathrm{d}$ of fresh leaves per feeding for all six does.

The does were milked twice every day and the milk was sampled every other day, frozen at $28^{\circ} \mathrm{F}$ and sent to the research laboratories of phytochemistry and toxicology at UC Irvine for analysis of urushiol content by High Performance Liquid Chromatography (HPLC) and infrared spectroscopy.

\section{Trial II: poison oak as $\mathbf{1 0 0} \%$ diet}

Four lactating goats from the UCD Dairy Goat Facility were individually housed in elevated calf pens in the calving barn of the Sierra Foothill Range Field Station (SFRFS) for 10 days. Poison oak foliage was collected every morning from the same field as trial I. Goats were individually offered an average of $1.7 \mathrm{~kg} / \mathrm{d}$ of freshly cut poison oak with no supplementation.

The refusals were weighed each following morning, the pens were cleaned, and

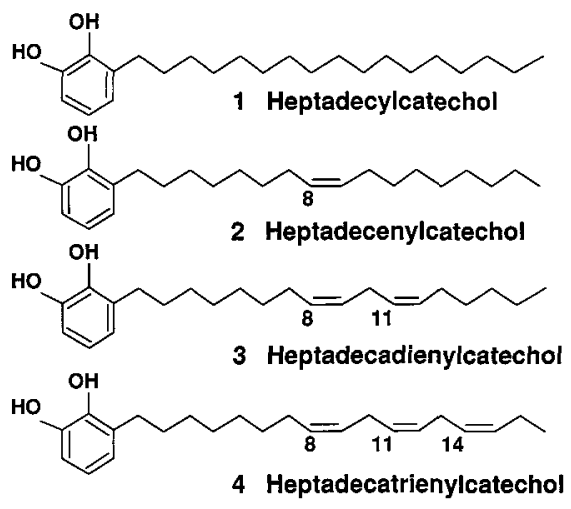

Fig. 1. Chemical structure of poison oak urushiol congeners.

the does were milked by hand. Milk yield was recorded at each milking, and the milk was sampled every other day, in addition to the first and last day of the trial. Fresh leaf samples were also collected for analysis of urushiol content, and the leaves oven-dried at $158^{\circ} \mathrm{F}$ were kept for analysis of nutritive value. Fresh leaves and milk samples were kept frozen at $28^{\circ} \mathrm{F}$ until analysis. On the trial's seventh day, does were catheterized for urine collection and fitted with fecal collection bags for total fecal collection for 48 hours. Feces and urine were kept frozen until extraction.

Leaves and feces were extracted with acetone $(15 \mathrm{ml} / \mathrm{g}$ ) for 4 days. The crude extract was filtered through Whatman \#1 paper. Ten $\mathrm{ml}$ of the filtrate were then evaporated to dryness under a nitrogen stream at room temperature. The oily residue was dissolved in $10 \mathrm{ml}$ of methylene chloride and evaporated to dryness. The remaining material was purified with hexane, water and acetonitrile. Milk and urine samples were not pre-extracted with ace- tone and methylene chloride. The purified solutions were injected through a $\mathrm{C}_{18}$ cartridge column and then filtered before HPLC analysis at UCD.

The eluent, a methanol/water mixture (90:10), was pumped by a Waters 510 HPLC pump through a Pico-Tag $\mathrm{C}_{18}$ reverse-phase column at $1.2 \mathrm{ml} / \mathrm{min}$. The UV detector (Waters 490) was set at 275 $\mathrm{nm}$. The retention times of the chromatograms were compared with those of the standards of the different urushiol congeners obtained from the UC Irvine laboratories (previously identified by IR and GC/ Mass Spectrometry).

The dry leaves were ground and analyzed for dry matter, ash, nitrogen, ether extract, acid detergent fiber (ADF), neutral detergent fiber, cellulose, lignin, calcium and phosphorus, according to standard procedures used at the UC Davis Animal Science Nutrition Laboratory.

The urine samples were analyzed for catechols by thin layer chromatography (TLC) using $\mathrm{KC}_{18} \mathrm{~F}$ plates and methanol: water (95:5) as solvent and sprayed with $1 \% \mathrm{FeCl}_{3}$. Heptadecatrienylcatechol obtained from UC Irvine was the standard reference catechol.

\section{Results}

No urushiol was found in the milk of trial I goats fed mature poison oak foliage for 3 days as $7 \%$ of their diet. For this reason, trial II was planned to challenge lactating does with a stall-fed diet of $100 \%$ poison oak foliage.

Table 1 gives the chemical composition of five dry samples of young leaves (first 2 to 3 weeks of seasonal growth) with a small portion of stem (the same portion of plant material consumed by the goats). The crude protein content was between 18

TABLE 1. Chemical composition of five samples of poison oak leaves on percent dry matter

\begin{tabular}{lcccccccccc}
\hline \hline ID\# & DM & Ash & N & EE & ADF & NDF & Cell & Lig & Ca & P \\
\hline 74 & 93.5 & 6.39 & 3.47 & 8.0 & 13.5 & 20.4 & 10.4 & 3.4 & 1.2 & .60 \\
75 & 94.6 & 6.95 & 2.91 & 6.9 & 16.7 & 23.7 & 12.7 & 3.8 & 1.2 & .40 \\
76 & 95.5 & 7.02 & 3.08 & 7.5 & 11.3 & 20.2 & 9.8 & 2.4 & 1.4 & .38 \\
77 & 93.4 & 6.95 & 3.18 & 7.0 & 13.7 & 20.1 & 11.2 & 2.9 & 1.1 & .54 \\
78 & 94.6 & 6.92 & 3.23 & 6.8 & 12.9 & 20.7 & 10.0 & 2.9 & 1.2 & .36 \\
Mean & 94.3 & 6.85 & 3.17 & 7.2 & 13.6 & 21.0 & 10.8 & 3.1 & 1.2 & .46 \\
\hline
\end{tabular}

${ }^{\star} D M=$ dry matter, $N=$ nitrogen, $E E=$ ether extract, $A D F=$ acid detergent fiber, $N D F=$ neutral detergent fiber Cell $=$ cellulose, $\mathrm{Lig}=$ lignin, $\mathrm{Ca}=$ calcium, $\mathrm{P}=$ phosphorus .

TABLE 2. Urushiol congeners concentration in leaf ( $g / g$ of leaf), feces $(\mathrm{g} / \mathrm{g}$ of feces) and feces urushiol/leaf urushiol

\begin{tabular}{lllc}
\hline \hline & Leaf & Feces & Ratio \\
\hline Heptadecatrienylcatechol(4) & .0209 & .000313 & $\%$ \\
Heptadecadienylcatechol(3) & .00259 & .00102 & 1.50 \\
Heptadecenylcatechol(2) & .00177 & .00081 & 39.5 \\
Heptadecylcatechol(1) & $\underline{.0068}$ & $\underline{.000652}$ & 4.8 \\
Total & $\underline{.00279}$ & .00279 & 8.7 \\
\hline
\end{tabular}


